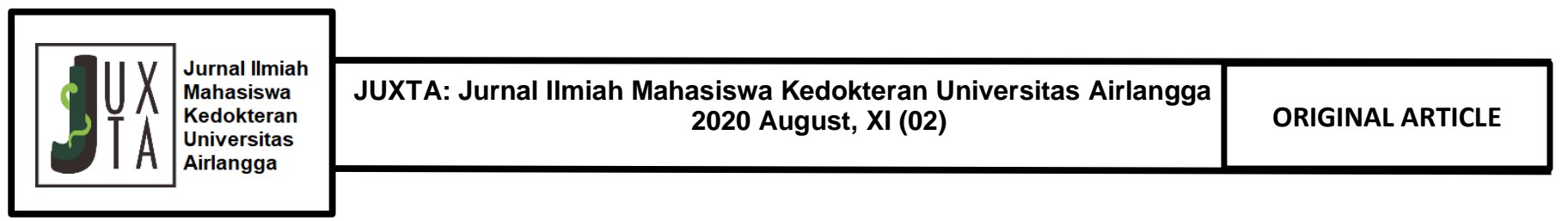

\title{
Risk Factors for Lower Extremity Amputation in Diabetic Foot Ulcer Patients: A Case-Control Study
}

\author{
Gusti Agung Ayu Ira Kencana Dewi ${ }^{1}$, Sony Wibisono ${ }^{2^{*}}$, I Putu Alit Pawana ${ }^{3}$
}

\begin{abstract}
${ }^{1}$ Faculty of Medicine, Universitas Airlangga, Surabaya, Indonesia.
2Department of Internal Medicine, Faculty of Medicine, Universitas Airlangga/Dr. Soetomo General Hospital Surabaya, Indonesia. ${ }^{3}$ Department of Physical Medicine and Rehabilitation, Faculty of Medicine, Universitas Airlangga/Dr. Soetomo General Hospital Surabaya, Indonesia.
\end{abstract}

\section{A B S T R A C T}

Introduction: Diabetes mellitus is a metabolic syndrome that is marked by higher blood glucose. The uncontrolled high blood glucose can lead to complication, such as diabetic foot. Diabetic foot is the most reason why diabetic patients are hospitalized. Diabetic foot that cannot heal may lead to lower extremity amputation. The purpose of this study was to describe the risk factors of lower extremity amputation in diabetic foot ulcer patients.

Methods: This study used a case-control study of diabetic foot patients in Dr. Soetomo General Hospital from January 2015 to December 2017. This study used the data from medical records in Inpatient Installation Department of Internal Medicine. Patients with diabetic foot ulcer and lower extremity amputation due to diabetes were included in this study. Incomplete medical records were excluded. Data of samples were divided to two groups, i.e. the amputation group and the nonamputation group with a ratio of 1:1. Risk factors of amputation that were analyzed were male, old age, and the history of ulcer/lower extremity amputation.

Results: Based on the data of 36 samples, there were 11 male patients $(61.1 \%)$ and 7 female patients (38.9\%) who experienced lower extremity amputation. The average age of amputation group was 59.61 years old with a range of ages from 39 to 72 years old. This study found the risk factors for lower extremity amputation in diabetic foot ulcer patients was the history of ulcer/amputation due to diabetes (OR $5.0,95 \% \mathrm{Cl} 1.065-23.464, \mathrm{p}=0.034)$.

Conclusion: The risk factor for lower extremity amputation in diabetic foot ulcer patients was the history of ulcer/amputation due to diabetes.

@ 2020 JUXTA: Jurnal IImiah Mahasiswa Kedokteran Universitas Airlangga.

Available at https://e-journal.unair.ac.id/juxta

* Correspondence: sony.wibisono@gmail.com

JUXTA: Jurnal IImiah Mahasiswa Kedokteran Universitas Airlangga

p-ISSN: 1907-3623; e-ISSN: 2684-9453

DOI: $10.20473 /$ juxta.V11122020.83-85

Open access under Creative Commons Attribution-ShareAlike 4.0 International License (CC-BY-SA) C) (i) (2)
ARTICLE INFO

\section{Article history:}

Received 10 June 2020

Received in revised form 6 July 2020

Accepted 16 July 2020

\section{Keywords:}

Diabetic Foot,

Amputation,

Risk Factors 


\section{Introduction}

Diabetes mellitus is a chronic metabolic syndrome that is marked by higher blood glucose. It can be caused by the pancreas that is unable to produce enough insulin or the produced insulin cannot be used by the body. Insulin is hormone that regulates blood glucose and is produced by the pancreas. ${ }^{1}$ World Health Organization (WHO) stated there were around 422 million people suffering from diabetes in the world in 2014. ${ }^{1}$ International Diabetes Federation (IDF) also stated there were around 10 million people suffering from diabetes in Indonesia in $2017 .{ }^{2}$

The uncontrolled high blood glucose levels can cause complications, such as retinopathy, nephropathy, cardiovascular disease, peripheral neuropathy, and diabetic foot ulcer. ${ }^{3}$ Diabetic foot ulcer is one of the most reasons why diabetic patients are hospitalized. In Semarang, Indonesia, out of 232 diabetic patients admitted to the hospital, there were 186 patients suffering from diabetic foot ulcer. ${ }^{4}$ Risk factors for diabetic foot ulcer are old age, male, smoking, ethnicity, experiencing diabetes for more than 10 years, history of diabetic foot ulcer/amputation, peripheral neuropathy, peripheral arterial disease, foot deformity, hypertension, uncontrolled blood glucose levels, and retinopathy. ${ }^{5}$

The unhealed ulcer can lead to lower extremity amputation. ${ }^{6}$ Diabetic foot ulcer is one of the highest causes of non-traumatic amputation in the world and the most feared consequences for diabetic patients. ${ }^{7}$ Risk factors for lower extremity amputation in diabetic foot ulcer patients are peripheral neuropathy, peripheral arterial disease, foot deformity, retinopathy, uncontrolled blood glucose level, history of diabetic foot ulcer/amputation, ${ }^{8}$ and old age. ${ }^{9}$ The purpose of this study was to determine the risk factors for lower extremity amputation in diabetic foot ulcer patients so that they could be prevented from amputation.

\section{Methods}

This study used a case-control study and was conducted in Dr. Soetomo General Hospital Surabaya, Indonesia. This study used medical records of diabetes mellitus type 2 patients in the Inpatient Installation Department of Internal Medicine from January 2015 to December 2017. Patients with diabetic foot ulcer and lower extremity amputation due to diabetes were included in this study. Incomplete medical records were excluded. This study assumed the proportion of diabetic foot ulcer with amputation was $39.5 \%{ }^{4}$ with an odds ratio (OR) 2.0 at $95 \%$ level of the confidence interval $(\mathrm{Cl})$ and minimal samples used at least 23 samples. The ethical of this study had already been approved by Committee Ethical of Faculty of Medicine Universitas Airlangga and Dr. Soetomo General Hospital Surabaya, Indonesia. This study used 1:1 matching design with one subject control for each case. The sampling technique used in this study was a simple random sampling. The independent variables used were old age, male, and history of ulcer/amputation in diabetic patients. This study used only three variables due to lack of medical records data. The data was analyzed using IBM SPSS Statistic 23.

\section{Results}

Total samples obtained were 55 patients with a population of amputation group were 23 patients. From 55 patients, only 36 met the sample criteria and were used in this study. There were 18 patients in the amputation group and 18 patients in the non-amputation group. In amputation group, there were 11 male patients $(61.1 \%)$ and 7 female patients (38.9\%). The average age of the amputation group was 59.61 years old with a range of ages from 39 to 72 years old. There were 9 patients $(50.0 \%)$ with the history of ulcer/amputation in the amputation group.

Table 1. Risk factors for lower extremity amputation in diabetic foot ulcer patients in Inpatient Installation Department of Internal Medicine Dr. Soetomo General Hospital from January 2015 to December 2017.

\begin{tabular}{|c|c|c|c|c|c|c|c|}
\hline \multirow[t]{2}{*}{$\begin{array}{l}\text { Vari- } \\
\text { able }\end{array}$} & \multicolumn{2}{|c|}{ Amputation } & \multicolumn{2}{|c|}{$\begin{array}{c}\text { Non- } \\
\text { Amputation }\end{array}$} & \multirow[t]{2}{*}{ OR } & \multirow[t]{2}{*}{$\begin{array}{c}95 \% \\
\mathbf{C l}\end{array}$} & \multirow{2}{*}{$\begin{array}{c}\mathbf{P} \\
\text { va- } \\
\text { lue }\end{array}$} \\
\hline & Tot & $\%$ & Tot & $\%$ & & & \\
\hline Sex & & & & & $\begin{array}{c}1.5 \\
7\end{array}$ & $\begin{array}{c}0.418 \\
-\end{array}$ & 0.50 \\
\hline Male & 11 & 61.1 & 9 & 50.0 & & 5.903 & \\
\hline $\begin{array}{l}\text { Female } \\
\text { Age } \\
\text { (years) }\end{array}$ & 7 & 38.9 & 9 & 50.0 & 2.5 & $\begin{array}{c}0.648 \\
-\end{array}$ & 0.18 \\
\hline $\begin{array}{l}\geq 60 \\
<60\end{array}$ & $\begin{array}{c}10 \\
8\end{array}$ & $\begin{array}{l}55.6 \\
44.4\end{array}$ & $\begin{array}{c}6 \\
12\end{array}$ & $\begin{array}{l}33.3 \\
66.7\end{array}$ & & 9.651 & \\
\hline $\begin{array}{l}\text { History } \\
\text { of ulcer/ } \\
\text { amputa- } \\
\text { tion }\end{array}$ & 9 & 50.0 & 3 & 16.7 & 5.0 & $\begin{array}{c}1.065 \\
- \\
23.46\end{array}$ & $0.03^{*}$ \\
\hline
\end{tabular}

\section{Discussion}

Diabetic foot ulcer is one of the most reasons why diabetic patients are hospitalized. ${ }^{4}$ In Indonesia, there are few studies on risk factors for amputation in diabetic foot patients. This study found that the history of ulcer/amputation in diabetic foot had a major role in the development of lower extremity amputation. Other studies reported that patients with the history of ulcer/amputation due to diabetic foot ulcers had five times greater risk for lower extremity amputation. ${ }^{1}$ Others stated that with the history of ulcer/amputations, these patients had the risk factors for recurrent ulcers. ${ }^{9}$

This study found that male and old age were not risk factors for lower extremity amputation in diabetic foot ulcer patients. These were different from other studies. Parisi, et al. (2016) found that male patient was the risk factor for lower extremity amputation in diabetic foot patients. ${ }^{10}$ They stated that male patients were not too worried about the disease so they rarely made hospital visits and did wound care compared to the female patients. ${ }^{10}$ Musa, et al. (2018) found that old age was the risk factor for lower extremity amputation in diabetic foot patients. ${ }^{6}$ They stated that elderly patients had poor prognosis in wound healing because of a reduced immune response to infection and other comorbid diseases that slowed wound healing. ${ }^{6}$ The 
difference in this study could be caused due to differences in the number of samples used. The sample in this study did not meet the minimum sample of 23 patients for each group so that the results could be affected. This happened because of the lack of medical records data needed.

\section{Conclusion}

In the result of our analysis, the history of ulcer/amputation in diabetic foot ulcer patients was independent risk factors for lower extremity amputation.

\section{CONFLICT OF INTEREST}

The author stated there is no conflict of interest in this study.

\section{REFERENCES}

1. Organization WH. Diabetes. Geneva: World Health Organization, 2017.

2. Federation ID. IDF Diabetes Atlas. 7th ed. Brussels: International Diabetes Federation, 2015.

3. Brownlee M, Aiello LP, Cooper ME, Vinik Al, Plutzky J and Boulton AJM. Chapter 33 - Complications of Diabetes Mellitus. In: Melmed S, Polonsky KS, Larsen PR and Kronenberg HM, (eds.). Williams Textbook of Endocrinology (Thirteenth Edition). Philadelphia: Content Repository Only!, 2016, p. 1484-581.
4. Pemayun TGD, Naibaho RM, Novitasari D, Amin N and Minuljo TT. Risk Factors for Lower Extremity Amputation in Patients with Diabetic Foot Ulcers: A Hospital-Based CaseControl Study. Diabet Foot Ankle. 2015; 6: 29629-.

5. Ahmad J. The Diabetic Foot. Diabetes \& Metabolic Syndrome: Clinical Research \& Reviews. 2016; 10: 48-60. 6. Musa IR, Ahmed MON, Sabir El, et al. Factors Associated with Amputation among Patients with Diabetic Foot Ulcers in a Saudi Population. BMC Res Notes. 2018; 11: 260.

7. Organization WH. Global Report on Diabetes. Geneva: World Health Organization, 2016.

8. Armstrong DG and Lavery LA. Diabetic Foot Ulcers: Prevention, Diagnosis and Classification. American Family Physician. 1998; 57: 1325-32, 37-8.

9. Wu S and Armstrong DG. Risk Assessment of the Diabetic Foot and Wound. International Wound Journal. 2005; $2: 17-24$.

10. Parisi MCR, Moura Neto A, Menezes FH, et al. Baseline Characteristics and Risk Factors for Ulcer, Amputation and Severe Neuropathy in Diabetic Foot at Risk: The BRAZUPA Study. Diabetol Metab Syndr. 2016; 8: 25-. 